\title{
Developing E-Book Contained Character Values in PPKn Lesson Content Grade V Elementary School
}

\author{
Putu Nita Filivani \\ Elementary School Teacher Education, Ganesha University of Education, Singaraja, Indonesia \\ e-mail:putunitafilivani27@undiksha.ac.id
}

Anak Agung Gede Agung

Education Technology, Ganesha University of Education, Singaraja, Indonesia e-mail:agungtps2056@gmail.com

\section{A R T I C L E I N F O \\ Article history: \\ 25 December 2020 \\ Received in revised form \\ 01 January 2021 \\ Accepted 25 January 2021 \\ Available online 03 Pebruari 2021 \\ Kata Kunci: \\ Pengembangan, E-Book, \\ Nilai-nilai Karakter, PPKn \\ Keywords: \\ Development, E-Book, \\ Character Values, Pancasila \\ and Civic Education (PPKn)}

\begin{abstract}
A B S T R A K
Guru kurang berinovasi dalam mengembangkan media sehingga interaksi siswa dalam pembelajaran daring tidak maksimal dan berakibat pada kurangnya penguatan nilai karakter bagi siswa. Media yang dikembangkan adalah E-Book bermuatan nilai-nilai karakter. Karena itu, penelitian bertujuan untuk mendeskripsikan proses rancang bangun produk E-Book bermuatan nilai-nilai karakter dan mengetahui hasil validasi E-Book menurut review para ahli, uji coba perorangan, dan uji coba kelompok kecil. Jenis penelitian yang dilakukan adalah penelitian pengembangan yang menerapkan model ADDIE (Analyze, Design, Development, Implementation, Evaluation). Pengumpulan data digunakan metode kuesioner. Analisis data digunakan metode analisis deskriptif kuantitatif. Hasil analisis data berdasarkan validasi media oleh ahli isi muatan pelajaran diperoleh Score $91,67 \%$ dengan kualifikasi sangat baik, ahli desain instruksional diperoleh Score 100\% dengan kualifikasi sangat baik, ahli media pembelajaran diperoleh Score $95,00 \%$ dengan kualifikasi sangat baik. Hasil uji pengguna perorangan pada 3 orang siswa diperoleh Score 95,83\% dengan kualifikasi sangat baik dan uji pengguna melalui uji kelompok kecil pada 12 orang siswa diperoleh Score 97,50\% dengan kualifikasi sangat baik. Berdasarkan hasil analisis data uji produk oleh para ahli (ahli isi muatan pelajaran, ahli desain instruksional, ahli media pembelajaran) dan hasil
\end{abstract} uji pengguna (siswa) disimpulkan bahwa media E-Book bermuatan nilai-nilai karakter adalah layak digunakan dalam pembelajaran muatan PPKn di kelas V SD. Implikasi pemanfaatan E-Book sebagai media pembelajaran berbasis teknologi ditunjang sarana dan prasarana yang ada di sekolah seperti akses internet (WiFi), perangkat komputer/laptop, LCD, proyektor, serta kesiapan dan keterampilan guru maupun siswa dalam mengakses media E-Book.

\begin{abstract}
A B S T R A C T
Teachers are not innovated in developing media, therefore students' interaction in online learning was not optimal. This issue raised a new problem such as, lack of deepening character values for students. The media developed was an E-Book containing character values. Therefore, this research aims to describe the design process of E-Book product with character values and find out the results of E-Book validation according to the results of expert reviews, individual try-outs, and small group try-outs. The type of this research was a development research by applying ADDIE model (analyze, design, development, implementation, evaluation). Then, data collection method which used was questionnaire and quantitative descriptive analysis method. The results of data analysis were gained based on media validation assessed by content learning experts obtained a score of $91,67 \%$ with very good qualifications, instructional design expert obtained a score of $100 \%$ with very good qualifications, learning media expert obtained a score of $95,00 \%$ with very good qualifications. The results of individual user test on 3 students obtained a score of $95,83 \%$ with very good qualifications, and the user test through small group test on 12 student obtained a score of $97,50 \%$ with very good qualifications. Based on the results of the product test data analysis by experts (content learning expert, instructional design expert, learning media expert) and user subject test results (students), it can be concluded that E-Book media containing character values were suitable to be used in PPKn learning subject for 5th grade elementary school students. The implication of using E-Book as technology-based learning media supported by existing facilities and infrastructure in schools such as internet access (WiFi), computers / laptops, LCDs, projectors, as well as the readiness and skills of teachers and students in accessing E-Book media.
\end{abstract}

\section{Introduction}

Along with the progress of science and technology (IPTEK), one of the important tasks in education is to build the character of the nation (character building) (Widiasworo, 2018). Character education is not only about knowledge but it is more about personality and students' daily behaviours (Amaruddin, Atmaja, \& Khafid, 2020; Asriani, Sa'dijah, \& Akbar, 2017). Real implementation of education by applying character values exists in KTSP (Padmadewi, 2015) and K13 curriculum in Indonesia for formal education started from elementary 
school until university level. In the application, education which contains intergrated character values directly exists in lesson content Pancasila and Civic Education (Pendidikan Pancasila dan Kewarganegaraan/PPKn). PPKn as conscious effort was conducted scientifically and psychologically to give an easy learning for students in order to internalize Pancasila moral and civic education to underlie the national education purpose which realizes by personal integration and daily behaviours (Kurniawan \& Saragih, 2016; Sriyanto, Leksono, \& Harwanto., 2019)

Learning activities in school can bring condusive situation in forming children characters (Asriani, 2017). But in Covid-19 pandemic situation learning activities are no longer carried out at schools, but conducted through an online learning at home based on government policy by the Ministry of Education and Culture in Indonesia. The change from off network (offline) to network (online) in the learning system had a big impact, especially for teachers who are threatened by the change of educational system (Chang et al., 2020; Rigianti, 2020). This was also felt by teachers in $5^{\text {th }}$ grade SD Negeri 1 Pemecutan. Based on the results of observations and interviews, it was known that teachers were difficult to integrate character values, especially in the PPKn lesson in online learning activities. Media based used in online learning activities was online media such as WhatsApp and Google Classroom. Through asynchronous assignment activities, the learning process was only based on the material in textbooks or other source books, therefore the strengthening of the attitude and character values in the learning material still unvisible. Padli (2020) stated that teachers were difficult to assess the affective and psychomotor aspects of students via WhatsApp, because the lack of interaction between teachers and students. This had an impact on decreasing students' interest in learning and knowledge competencies. Apart from being limited in space and time, the use of less innovative and varied media was another reason. Therefore, to achieve the educational objectives of building national character, it is necessary to develop an appropriate learning media. According to (Sukiman, 2012) the success of the learning process occured due to the attention, stimulation of thoughts, and feelings of students in learning obtained through the media.

Based on these problems, a learning media in the form of an E-Book was developed as a form of technology use in online learning activities. E-book stands for electronic book or buku elektronik in the form of textbooks that are converted into digital format (Fathoni \& Marpanaji, 2018; Puspitasari \& Rakhmawati, 2013). E-book contains information in the form of text, image, and audio which are packaged in a file (Muswita, Utomo, Yelianti, \& Wicaksana, 2018; Wahyuni, 2014). E-Book has several advantages such as saving papers, can be accessed anywhere and anytime, and contain various other learning activities in it. With the various activities in the E-Book with character values, it is expected that it can help teachers to overcome problems in the online class. The e-book developed in this study was made in html format, therefore it can be used either through smartphone or other digital devices such as computers or laptops. This E-Book development is expected to increase students' interest in learning and help students to learn independently in online learning activities. Advantages of this E-Book can be accessed repeatedly contained PPKn materials accompanied by deepening the character values, images, and relevant integrated YouTube videos as well as an independent evaluation for students by using Google Form link. The advantages of the E-Book are supported by the results of previous studies.

Wulandari (2019) conducted a study in developing E-Book. Based on the research, it is known that the developed E-Book was effective to be used in independent learning activities with 95, 34\% of students experiencing increased learning outcomes. E-Book designed such a way to make students understand the material in a fun, easy, and practical way. Another similar research was conducted by (Astuti \& Muslim, 2018; Fathoni \& Marpanaji, 2018). The results showed that the developed E-Book was effectively used in learning activities. E-Books can be used to help build students' positive character through PPKn lesson (Suhaida \& Fadillah, 2019). Besides, research by (Wijayanto, 2017) showed that electronic school books can be used as a solution to the problem of providing books and can be used by students independently to measure the level of material understanding. In line with this research, the development of this E-Book also expected to help teachers build character values for students.

Saddhono (2019) mentioned that developing E-Book was very important since in general the EBook that was developed in the form of PDF document for which data is static, therefore a pattern of reading tend to be less attractive. Meanwhile, the E-Book that contains character values was developed with various features such as (flip menu, thumbnail, search, and accompaniment music) so that it becomes more attractive to be used by students. Strengthening character values in the material was the main focus of the development. Therefore, the purpose of this study was to describe the process of designing E-Book containing character values and identify validation E-Book according to results of review experts, individual try-out, and small group tryout. This development expected to overcome the limitations of media and learning tools, which make it difficult for students to implement and equate experiences regarding the character values that appear in online learning, and then the learning objectives to build the character of the nation can be achieved. 


\section{Method}

The type of this research was development research $(\mathrm{R} \& \mathrm{D})$ where the E-Book development process was conducted by applying the ADDIE model. According to (Tegeh, dkk., 2014) the ADDIE model has systematic steps to solve learning problems related to learning resources according to the needs and learning characteristics of students. This opinion in line with the objectives of the research conducted, as an effort to develop useful products to support and solve problems in learning activities. ADDIE consisted of five steps, namely analysis, design, development, implementation, and evaluation, which are easy to be understood and implemented in the research product development process (Wisada dkk., 2019).

The first stage was the analysis stage. In the analysis stage, the needs of teachers and students in learning material and environment, and students' learning facilities were alayzed. The second stage was the design stage, started from product design process for designing a product before it developed and it included with the determination of hardware and software, creation of flowcharts and storyboards, the lesson plan (RPP) designing, as well as product assessment instruments in the form of a questionnaire. The third stage was the development started from producing the E-Book until product assessment which has been developed by experts and students. The fourth stage was implementation which included with the summative evaluation through teaching and learning process which cannot be conducted directly in the classroom. The last was the stage of evaluation. Formative evaluation was carried out during the development process, the goal was in order to minimize errors in the process of development. At the analysis stage, there was an evaluation process to analyze the needs of teachers and students in learning, the evaluation process design stage to see the completeness of the E-Book development plan and at the development stage, the evaluation process was to determine the feasibility of the product through a try-out process by experts and students. The results obtained from product try-out were used as a reference for repairing or perfecting the developed product.

This research was conducted at SD Negeri 1 Pemecutan. In this research, product was assessed by experts and students. The experts consisted of 1 subject content expert who is a Pancasila education lecturer, 1 instructional design expert, and 1 instructional media expert namely a lecturer with educational technology qualifications. While individual user try-out involved 3 students of grade V in SD Negeri 1Pemecutan, and small group user try-out involved 12 students of grade V in SD Negeri 1 Pemecutan.

The data collection method in this development research used a questionnaire method. The data analysis method used in this development research was quantitative descriptive analysis method. The quantitative descriptive method is a way to process data systematically into numbers or percentages to get general conclusions (Agung, 2014:110). In this research, quantitative descriptive analysis was used to data process obtained from the experts (lesson content expert, instructional design expert, and instructional media expert) and the students through questionnaires in the form of scores. The questionnaire used a Likert scale with even choice categories. The E-Book questionnaire instrument grid containing character values is as follows.

Table 1. Lesson Content Expert Instrument Grid

\begin{tabular}{|c|c|c|c|c|}
\hline No. & Aspect & Indicator & $\begin{array}{c}\text { Item } \\
\text { Number }\end{array}$ & $\begin{array}{l}\text { Total } \\
\text { Item } \\
\end{array}$ \\
\hline \multirow{3}{*}{1.} & \multirow{3}{*}{ Curriculum } & a. Suitability of material with basic competencies & 1 & \multirow{3}{*}{3} \\
\hline & & b. Suitability of material with indicators & 2 & \\
\hline & & c. Suitability of material with learning objectives & 3 & \\
\hline \multirow{7}{*}{2.} & \multirow{7}{*}{ Material } & a. Suitability of material with student characteristics & 6 & \multirow{7}{*}{7} \\
\hline & & b. Depth of material & 4 & \\
\hline & & c. The material is supported by the right media & 8 & \\
\hline & & d. The material is easy to understand & 7 & \\
\hline & & e. The material represents real life & 9 & \\
\hline & & f. Provide another resource for learning & 5 & \\
\hline & & g. Use of appropriate and consistent language & 10 & \\
\hline \multirow{3}{*}{3.} & \multirow[b]{2}{*}{ Evaluation } & a. The suitability of the evaluation with the material & 12 & \multirow[b]{2}{*}{2} \\
\hline & & $\begin{array}{l}\text { b. The suitability of the difficulty level of the questions with } \\
\text { the competence }\end{array}$ & 11 & \\
\hline & & Total & & 12 \\
\hline
\end{tabular}


Table 2. Instructional Design Expert Instrument Grid

\begin{tabular}{|c|c|c|c|c|}
\hline No & Aspect & Indicator & $\begin{array}{c}\text { Item } \\
\text { Number }\end{array}$ & $\begin{array}{l}\text { Total } \\
\text { Item }\end{array}$ \\
\hline \multirow{3}{*}{1} & \multirow{3}{*}{ Purpose } & a. $\quad$ Clarity of learning objectives & 1 & \multirow{2}{*}{2} \\
\hline & & b. Consistency between objectives, materials, and evaluation & 2 & \\
\hline & & a. Systematic delivery of material & 5 & \multirow{4}{*}{4} \\
\hline \multirow{4}{*}{2} & \multirow{4}{*}{ Strategies } & b. Be able motivate students & 4 & \\
\hline & & c. Provide attention grabbers & 3 & \\
\hline & & d. Provide students with opportunities to study independently & 6 & \\
\hline & & a. Provide evaluation questions to test student understanding & 8 & \multirow[b]{2}{*}{2} \\
\hline \multirow[t]{2}{*}{3} & Evaluation & $\begin{array}{l}\text { b. The questions presented are in accordance with the learning } \\
\text { indicators }\end{array}$ & 7 & \\
\hline & & Total & & 8 \\
\hline
\end{tabular}

Table 3. Learning Media Expert Assessment Instruments Grid

\begin{tabular}{|c|c|c|c|c|}
\hline No & Aspect & Indicator & $\begin{array}{c}\text { Item } \\
\text { Number }\end{array}$ & $\begin{array}{l}\text { Total } \\
\text { Item }\end{array}$ \\
\hline \multirow{3}{*}{1.} & \multirow{3}{*}{ Technical } & a. $\quad$ Ease of using media & 1 & \multirow{3}{*}{3} \\
\hline & & b. Media can help students understand the material & 3 & \\
\hline & & c. Media can generate student motivation & 2 & \\
\hline \multirow{3}{*}{2.} & \multirow{3}{*}{ Display } & a. Good display quality & 4 & \multirow{3}{*}{2} \\
\hline & & b. The screen display is harmonious and balanced & 5 & \\
\hline & & a. The accuracy of using fonts & 8 & \\
\hline \multirow[t]{2}{*}{3.} & \multirow[t]{2}{*}{ Text } & b. The accuracy of using the font size & 7 & \multirow[t]{2}{*}{3} \\
\hline & & c. The accuracy of using writing spacing & 6 & \\
\hline \multirow{3}{*}{4.} & Picture and & a. The use of pictures in the E-Book supports learning & 9 & \multirow{2}{*}{2} \\
\hline & Video & b. Use of videos that support understanding of the material & 10 & \\
\hline & & Total & & 10 \\
\hline
\end{tabular}

(Source: Suartama, 2016)

Table 4. Individual and Small Group Try-Out Instrument

\begin{tabular}{|c|c|c|c|c|}
\hline No & Aspect & Indicator & $\begin{array}{c}\text { Item } \\
\text { Number }\end{array}$ & $\begin{array}{l}\text { Total } \\
\text { Item }\end{array}$ \\
\hline \multirow{4}{*}{1} & \multirow{4}{*}{$\begin{array}{l}\text { Display } \\
\text { Design }\end{array}$} & a. Attractiveness of E-Book display & 1 & \multirow{4}{*}{4} \\
\hline & & b. Text legibility & 2 & \\
\hline & & c. Image clarity & 3 & \\
\hline & & $\begin{array}{l}\text { d. Clarity of instructions for using links (Google } \\
\text { Form \& Youtube) }\end{array}$ & 4 & \\
\hline \multirow{3}{*}{2} & \multirow{3}{*}{ Material } & a. The material is easy to understand & 5 & \multirow{3}{*}{3} \\
\hline & & b. Clarity of material description & 8 & \\
\hline & & c. Media gives students enthusiasm in learning & 7 & \\
\hline \multirow{3}{*}{3} & \multirow{3}{*}{ Evaluation } & a. Clarity of instructions for working on questions & 6 & \multirow{3}{*}{3} \\
\hline & & b. The questions are in accordance with the material & 9 & \\
\hline & & c. Language is easy to understand & 10 & \\
\hline
\end{tabular}

(Source: Sudarma, 2015)

The set criteria which gives the meaning of conversion to the percentage score and the decision making of the feasibility of the product being developed are as follows. 
Table 5. Conversion of Achievement Level Scale 5

\begin{tabular}{cccc}
\hline No & Achievement Rate (\%) & Qualification & Explanation \\
\hline 1. & $90-100$ & Very good & No need to revise \\
2. & $75-89$ & Good & Little revision \\
3. & $65-74$ & Enough & Enough revision \\
4. & $55-64$ & Less & Many things to revised \\
5. & $0-54$ & Very less & Re-create the product \\
\hline
\end{tabular}

(Source: Tegeh \& Kirna, 2010)

\section{Result and Discussion}

The results of this development research included two main points, namely: (1) E-Book product development design and (2) E-Book product validation. The design and development of this E-Book development process applied the ADDIE development model which includes the step of the analysis, design, development, implementation, and evaluation (Tegeh, 2014). In the process of developing this product, there are limitations at the implementation stage. Implementation is the application of development products that are suitable for widespread use in the learning process to determine the effectiveness of the product. Meanwhile, this research was conducted during the Covid-19 pandemic so that the implementation stage which includes summative evaluation activities through teacher and student learning directly in the classroom cannot be implemented. The development stage which has been conducted is as follows.

The first finding in the learning analysis stage through the results of interviews showed that the online learning system force students to be able to learn independently, so the skills of teachers are needed in creating a conducive learning climate through the development of appropriate learning media especially media that focuses on strengthening student character. It is because the interaction between teachers and students in online learning is still not optimal, making it difficult for teachers to reach the affective aspects of students in learning. Analysis of student learning needs through questionnaires found that students were very happy to learn using innovative and practical media such as E-Books, instructional videos, or interesting image media, not just using books obtained from school. Analysis of student learning facilities was condicted by observation to see student learning facilities both at school and independently. The result is the school already has an LCD projector, speaker, WiFi. In average, students also have learning facilities such as mobile phone or personal laptop. Students are already adept at using electronic media such as mobile phone, laptop or PC.

Design process stage was conducted for designing product before being developed which includes some activities (a) Determine the hardware and software used to maximize the development of the E-Book (b) Create a flowchart as an E-Book development flow. (c) Compile a storyboard to describe the material and learning activities arranged in the E-Book. (d) Prepare a lesson plan (RPP) as a reference for implementing learning activities using online and offline E-Books. (e) Develop an assessment instrument products in the form of questionnaires used by the experts and students to determine the feasibility of the developed E-Book.

Development stage was started from producing the E-Book until assessing products that have been developed by experts and students to determine the feasibility of the product before it is used in the learning process. The development stage started from (a) the preparation of learning materials in the E-Book with the help of the Microsoft Office Power Point application based on the previous design, (b) collecting images which were relevant to the material in the E-Book through the google site, online thematic books , and other sources, (c) searching for learning videos that are relevant to the material in the E-Book through the YouTube website, (d) combining relevant images to the material in the E-Book in the Microsoft Office Power Point application, (e) preparing evaluation questions related to the material in the E-Book in Google Form , (f) converting E-Book files in Microsoft Office Power Point into a PDF form, $(\mathrm{g})$ upload E-Book files in the form of PDF into the app Flip PDF Corporate, (h) merging YouTube video link and evaluation questions on Google Form link in E-Book, (i) publishing e-book in html links and exe file. After the E-Book had been produced, the next was the implementation of product try-out by experts, namely lesson content experts, instructional design expert, instructional media expert, and students through individual and small group try-out. Product try-out were conducted to determine the feasibility of the products to be used in the learning process.

Product evaluation try-out was conducted by experts and students. The try-out activity aims to determine the feasibility level of the product being developed. The product try-out process was assessed using a questionnaire instrument. Learning content is assessed by lesson content expert who is the lecturer in Pancasila lesson, learning design and media was assessed by expert which is qualified in education technology. Individual try-out was conducted by three students in class $\mathrm{V}$ which have high, medium and low learning outcomes in SD Negeri 1 Pemecutan, and the small group try-out was conducted by 12 students of class V SD Negeri 1 
Pemecutan with heterogeneous abilities, where each group have the same abilities. The following are the results of product try-out by experts and students.

Table 6. E-Book Product Try-Out Result Percentage Score

\begin{tabular}{ccccc}
\hline No & Respondents & Result $\mathbf{( \% )}$ & Qualification & Explanation \\
\hline 1. & Learning Content Expert & 91.67 & Very good & Very feasible, no need to revise \\
2. & Learning Design Expert & 100,00 & Very good & Very feasible, no need to revise \\
3. & Learning Media Expert & 95,00 & Very good & Very feasible, no need to revise \\
4. & Individual Try-out & 95.83 & Very good & Very feasible, no need to revise \\
5. & Small Group Try-out & 97.50 & Very good & Very feasible, no need to revise \\
\hline
\end{tabular}

Based on the results of product try-outs that have been carried out by lesson content expert, the result is $91.67 \%$ with very good qualifications. Instructional design expert got $100 \%$ with very good qualifications. Instructional media expert obtained $95,00 \%$ in percentage score with excellent qualifications. The results of individual try-outs got $95,83 \%$ with very good qualifications. The results of the small group try-out obtained $97,50 \%$ with very good qualifications. From the test results, it can be concluded that the developed E-Book product is very suitable for use in the learning process and does not need to be revised. However, in the product try-out process, there are comments / responses and suggestions from experts that can be taken into consideration for the improvement of the product. Below is the summary of comments and suggestions provided by experts and test subjects.

Table 7. Comments and Revisions

\begin{tabular}{|c|c|c|c|}
\hline No & Respondents & Comment & Revision \\
\hline 1. & $\begin{array}{l}\text { Lesson Content } \\
\text { Expert }\end{array}$ & $\begin{array}{l}\text { Expand the material } \\
\text { description concerning } \\
\text { concepts, values, morals, and } \\
\text { norms. }\end{array}$ & $\begin{array}{l}\text { Changing the formulation of learning } \\
\text { objectives in order to provide meaningful } \\
\text { learning experiences to students through } \\
\text { reading, observing the environment and } \\
\text { discussion. } \\
\text { Adding material coverage by deepening the } \\
\text { concepts, values, morals, and norms } \\
\text { through the corner column characters, "do } \\
\text { you know?", the characters, and the } \\
\text { keywords in the E-Book. }\end{array}$ \\
\hline 2. & $\begin{array}{c}\text { Learning Design } \\
\text { Expert }\end{array}$ & Very good & - \\
\hline \multirow[t]{2}{*}{3.} & $\begin{array}{l}\text { Learning Media } \\
\text { Expert }\end{array}$ & $\begin{array}{l}\text { The text and background on } \\
\text { the cover page need to be } \\
\text { contrasted more } \\
\text { Include a number and title in } \\
\text { the image }\end{array}$ & $\begin{array}{l}\text { Increase the contrast of the text and } \\
\text { background cover in E-Book } \\
\text { Include the number, title, and source of the } \\
\text { pictures in the E-Book }\end{array}$ \\
\hline & & $\begin{array}{l}\text { Add the identity of the } \\
\text { supervisor }\end{array}$ & $\begin{array}{l}\text { Adding the identity of the supervisor and } \\
\text { gratitude at the closing of the } E \text {-Book }\end{array}$ \\
\hline & No & & pondents \\
\hline & $\begin{array}{l}1 . \\
2 . \\
3 .\end{array}$ & $\begin{array}{c}\text { The } \\
\text { Int } \\
\text { L }\end{array}$ & $\begin{array}{l}\text { Book is great } \\
\text { sting } e \text {-Book } \\
\text { of picture }\end{array}$ \\
\hline
\end{tabular}


Table 9. Student Comments and Suggestions on the Small Group Try-Out

\begin{tabular}{cc}
\hline No & Respondents \\
\hline 1. & E-Books really helps us in learning \\
2. & The material in the E-Book is easy to understand \\
3. & Very nice \\
\hline
\end{tabular}

The display of the E-Book product development containing character values in the PPKn lesson content for grade $\mathrm{V}$ elementary school (SD) is as follows.

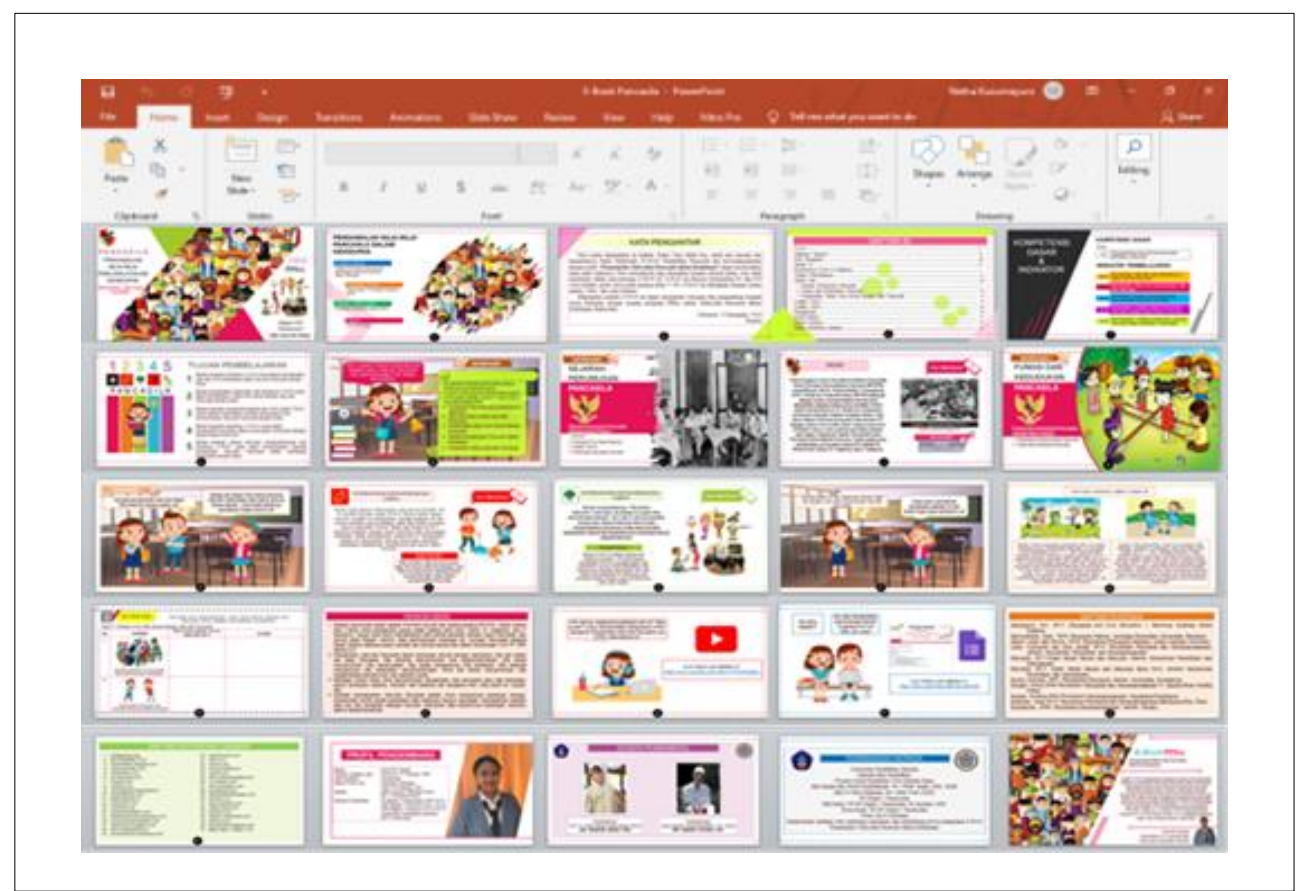

Figure 1. Development Results and Component Assembly of the E-Book

Based on the results of the research which had been conducted, the development of E-Books obtained very good qualifications from the assessment of experts and students, so that the developed E-Book is very suitable for use in the learning process. E-Book development obtains excellent results and very fit for use in the learning process because products development stage was using ADDIE development model.

Based on assessment from lesson content expert, E-Book obtained excellent qualifications. The quality of the curriculum, material, and evaluation aspects in the assessment instrument was spread over a score of 3 (good) and 4 (very good). The basic competencies, indicators and learning objectives used in the E-Book are in accordance with the material in the curriculum so that the learning activities in the E-Book are truly able to achieve learning objectives. According to Churri (2013) learning material should be relevant to the achievement of competency standards and the achievement of basic competencies that are reflected in the learning objectives. The developed E-Book contains material concepts for students to know about values, norms, and the practice of character values through PPKn lesson that support the achievement of learning objectives. Improving student character can be achieved through PPKn learning (Sapulette \& Wardana, 2016; Sriyanto et al., 2019).

Based on instructional design expert, E-Book is very well qualified. The learning objectives in the media and lesson plans are formulated using the ABCD format (audience, behavior, condition, degree). The comments received from instructional design expert are very good where the E-Book is able to provide meaningful learning activities, through observing pictures, videos and independent evaluation activities. Learning activities are able to develop student learning skills to build knowledge and makes learning meaningful (Putri \& Arifin, 2017). E-Book is supported by strengthening character values in character corners, as well as introducing national figures, and practice questions on each sub-material. Another comment is related to providing motivation to learn by using accompaniment music. Regular accompaniment music arrangements make students motivated to learn. For the accompaniment music, comments are also given, namely choosing music that is more calming and not too crowded, in line with the opinion by (Mayer, 2009; Widyaningrum, 2015) that busy accompaniment music can disturb students' focus in understanding the learning material. 
Based on the assessment from instructional media expert, E-Book obtained excellent qualifications. There are four aspects that are assessed, namely technical aspect, display aspect, text, images and videos. Based learning media expert comment, E- Book is very easy to use by only clicking the link provided then studied each page and the E-Book also contains other instructions. By using an E-Book, of course it can be read repeatedly to understand the material better. E-Book can be used repeatedly anywhere at any time (Almas \& Krismayani, 2019; Wulandari et al., 2019). The text aspect got a good qualification average. In terms of appearance, the EBook is attractive; the harmony of the screen display with the selection of background color and text is very good. The choice of font is adjusted to opinion by (Sudarma, 2015) namely the sans serif typeface. The images and videos qualify very well. Based on expert comments, the images selected are in accordance with the material and videos integrated in the E-Book have the right duration.

At the stage of try-out of individual and small group test, E-Book obtained excellent qualifications. Students gave positive comments towards the developed E-Book, some of the comments such as media is very attractive and easily understood in line with research conducted by (Audie, 2019) that the instructional media in creative and innovative is necessary so that learners are not bored and learning process is not monotonous so it can be conducted without any problems.

It is empirically proven that E-Book learning media which contains character values used in the learning activities especially PPKn lesson content very well. Based on results of try-out by experts and students, it got positive comments in the media development of the E-Book. This is supported by Suhaida's research which states that E-Books can be used to help build positive character of students through PPKn lesson (Suhaida \& Fadillah, 2019). In addition, research by (Wijayanto, 2017) shows that electronic school books can be used as a solution to the problem of providing books and can be used by students independently to measure the level of understanding of the material. E-books as learning media can increase student interest in learning and help students learn independently according to learning objectives. The implication of using E-Books as technologybased learning media supported by existing facilities and infrastructure in schools such as internet access (WiFi), computers / laptops, LCDs, projectors, as well as the readiness and skills of teachers and students in accessing E-Book media with character values in the grade V SD PPKn lesson content.

\section{Conclusion}

Based on the results of the analysis of product test data by experts (lesson content expert, instructional design expert, instructional design expert, learning media expert) and user testing (students), it is concluded that $E$ - Book media which contains character values worthy of use in learning activities on PPKn Lesson Content grade V Ementary School (SD).

\section{References}

Agung, A. A. (2014). Buku Ajar Metodelogi Penelitian Pendidikan. Yogyakarta: Aditya Media Publishing.

Almas, I., \& Krismayani, I. (2019). Kaji Tindak Penggunaan Meme Dalam Kegiatan Promosi Koleksi Ebook Di Perpustakaan Sma Negeri 3 Semarang. Jurnal Ilmu Perpustakaan, 6(3), 441-450. Retrieved from https://ejournal3.undip.ac.id/index.php/jip/article/view/23176/21201

Amaruddin, H., Atmaja, H. T., \& Khafid, M. (2020). Peran Keluarga Dan Media Sosial Dalam Pembentukan Karakter Santun Siswa Di Sekolah Dasar. Jurnal Pendidikan Karakter, 10(1). https://doi.org/https://doi.org/10.21831/jpk.v10i1.30588.

Asriani, P., Sa'dijah, C., \& Akbar, S. (2017). Bahan Ajar Berbasis Pendidikan Karakter Untuk. Jurnal Pendidikan: Teori, Penelitian, Dan Pengembangan, 2(11), 1456-1468. https://doi.org/http://dx.doi.org/10.17977/jptpp.v2i11.10160

Astuti, \& Muslim. (2018). Perencanaan dan Analisis E-Book Interaktif Materi ASEAN. Jurnal Informatika Sunan Kalijaga, 2(3). https://doi.org/http://dx.doi.org/10.14421/jiska.2018.23-01.

Audie, N. (2019). Peran Media Pembelajaran Meningkatkan Hasil Belajar Peserta Didik. Prosiding Seminar Nasional Pendidikan FKIP, 2(1), 586-595. Retrieved from https://jurnal.untirta.ac.id/index.php/psnp/article/view/5665

Chang, T. Y., Hong, G., Paganelli, C., Phantumvanit, P., Chang, W. J., Shieh, Y. S., \& Hsu, M. L. (2020). Innovation of dental education during COVID-19 pandemic. Journal of Dental Sciences, 1(155). https://doi.org/10.1016/j.jds.2020.07.011

Churri, M., \& Agung, Y. (2013). Pengembangan Materi Dan Media Pembelajaran Mata Pelajaran Dasar Kompetensi Kejuruan Teknik Audio Video Untuk Smk Negeri 7 Surabaya. Jurnal Pendidikan Teknik 
Elektro, 2(2), 803-809. Retrieved from https://jurnalmahasiswa.unesa.ac.id/index.php/jurnalpendidikan-teknik-elektro/article/view/4198

Fathoni, M. I., \& Marpanaji, E. (2018). Pengembangan e-book interaktif mata pelajaran teknologi informasi dan komunikasi (TIK) untuk SMK kelas X. Jurnal Inovasi Teknologi Pendidikan, 5(1), 70-81. https://doi.org/10.21831/jitp.v5i1.17149

Kurniawan, D., \& Saragih, A. H. (2016). Pengembangan Bahan Pembelajaran Media Interaktif Pada Mata Pelajaran Ppkn. Jurnal Teknologi Informasi \& Komunikasi Dalam Pendidikan, 3(1), 1-13. https://doi.org/10.24114/jtikp.v3i1.5001

Mayer, R. E. (2009). Multimedia Learning (U. Maska, ed.). Yogyakarta: Pustaka Pelajar.

Muswita, Utomo, A. B., Yelianti, U., \& Wicaksana, E. J. (2018). Pengembangan E-Book Berbasis Mobile Learning Pada Mata Kuliah Struktur Tumbuhan. Pendidikan Biologi, 11, 93-104. https://doi.org/https://doi.org/10.20961/bioedukasi-uns.v11i2.23814

Padli, F., \& Rusdi. (2020). Respon Siswa dalam Pembelajaran Online Selama Pandemi. Social Landscape Journal, 1(3), 1-7. Retrieved from https://ojs.unm.ac.id/SLJ/article/view/14508

Padmadewi, N. N. (2015). Pengembangan Perangkat Pembelajaran Berbasis Pendidikan Karakter Untuk Mata Kuliah Strategi Pembelajaran Bahasa Jurusan Pendidikan Bahasa Jepang Di Universitas Pendidikan Ganesha Singaraja. JPI (Jurnal Pendidikan Indonesia), 4(1), 540-555. https://doi.org/10.23887/jpiundiksha.v4i1.4893

Puspitasari, \& Rakhmawati. (2013). Pengembangan E-Book Interaktif Pada Mata Kuliah Elektronika Digital. Jurnal Pendidikan Teknik Elektro, 2(2). Retrieved from https://jurnalmahasiswa.unesa.ac.id/index.php/jurnal-pendidikan-teknik-elektro/article/view/2805

Putri, M. D., \& Arifin, R. R. M. (2017). PENGARUH PENERAPAN MODEL CORE Program Studi Pendidikan Guru Sekolah Dasar. Jurnal Khazanah Sekolah Dasar, 5(1), 111-123.

Rigianti, H. A. (2020). Kendala Pembelajaran Daring Guru Sekolah Dasar Di Banjarnegara. Elementary School: Jurnal Pendidikan Dan Pembelajaran Ke-SD-An, https://doi.org/https://doi.org/10.31316/esjurnal.v7i2.768

Saddhono, K., Sulaksono, D., \& Rahim, R. (2019). Pengembangan E-Book Interaktif Bipa Bermuatan Kearifanlokal Dengan Pendekatan Scientific-Thematic. Konferensi Internasional Pengajaran Bahasa Indonesia Bagi Penutur Asing (KIPBIPA) XI, 389-401.

Sapulette, M. S., \& Wardana, A. (2016). Peningkatan Karakter Siswa Kelas IV SD Negeri 16 Ambon Melalui Pembelajaran PPKn Dengan Media Cerita Rakyat. Harmoni Sosial: Jurnal Pendidikan IPS, 3(2), 150165. https://doi.org/10.21831/hsjpi.v3i2.11922

Sriyanto, Leksono, \& Harwanto. (2019). Bahan Ajar PPKn Berbasis Karakter dan Literasi Untuk Siswa Kelas IX SMP Al Hikmah Surabaya. Edmotech, 4(2), 130-142. https://doi.org/http://dx.doi.org/10.17977/um039v4i22019p130

Suartama, I. K. (2016). Materi 4 Evaluasi dan Kriteria Kualitas Multimedia Pembeajaran Oleh: I Kadek Suartama Jurusan Teknologi Pendidikan Universitas Pendidikan Ganesha Tahun 2016. (September), $1-18$.

Sudarma, I. K., Teguh, I. M., \& Prabawa, D. G. A. P. (2015). Desain Pesan Kajian Analitis Desain Visual Teks dan Image. Yogyakarta: Graha Ilmu.

Suhaida, D., \& Fadillah, S. (2019). Media Kajian Kewarganegaraan membentuk karakter siswa. Jurnal Civics: Media Kajian Kewarganegaraan, $\quad 16(2), \quad 111-121$. https://doi.org/https://doi.org/10.21831/jc.v16i2.21757

Sukiman, D., \& Pd, M. (2012). Pengembangan Media Pembelajaran, Yogyakarta: Pedagogia: PT. Pustaka Insan Madani.

Tegeh, I. M., Jampel, I. N., \& Pudjawan, K. (2014). Model Penelitian Pengembangan. Singaraja: Universitas Pendidikan Ganesha.

Tegeh, I. M., \& Kirna, I. M. (2010). Metodelogi Penelitian Pengembangan Pendidikan. Singaraja: Universitas Pendidikan Ganesah. 
Wahyuni, S. (2014). Pengembangan Interactive E-Book Bidang Asesmen Bahasa Untuk Mengembangkan Kompetensi Dan Kemandirian Mahasiswa Program Pendidikan Bahasa. Litera, 13(1). https://doi.org/https://doi.org/10.21831/ltr.v13i1.1908

Widiasworo, E. (2018). Strategi pembelajaran edutainment berbasis karakter. Yogyakarta: Ar-Ruzz Media.

Widyaningrum, H. K. (2015). Penggunaan Media Audio untuk Meningkatkan Kemampuan Menyimak Dongeng Anak pada Siswa Kelas IV Sekolah Dasar. Premiere Educandum Jurnal Pendidikan Dasar Dan Pembelajaran, 5(2). https://doi.org/http://doi.org/10.25273/pe.v5i02.284

Wijayanto, W., Menarianti, I., \& Wibisono, A. (2017). Pengembangan Buku Sekolah Elektronik (BSE) Dilengkapi Media Evaluasi Mandiri Siswa Berbasis Protable Document Format. Jurnal Informatika Upgris, 2(2), 83-89. https://doi.org/10.26877/jiu.v2i2.1110

Wisada, P. D., Sudarma, I. K., \& Yuda S, A. I. W. I. (2019). Pengembangan Media Video Pembelajaran Berorientasi Pendidikan Karakter. Journal of Education Technology, 3(3), 140. https://doi.org/10.23887/jet.v3i3.21735

Wulandari, V., Abidin, Z., \& Praherdhiono, H. (2019). Pengembangan Media Pembelajaran E-Book Infografis Sebagai Penguatan Kognitif Siswa X MIA. Jurnal Kajian Teknologi Pendidikan, 2(1), $37-44$. https://doi.org/http://dx.doi.org/10.17977/um038v2i12019p037 